\title{
Trust and Perceived Risk toward Actual Online Purchasing: Online Purchasing Intention as Mediating Variable
}

\author{
Septi Diana Sari ${ }^{\mathrm{a}}$, Ratri Nurina Widyanti ${ }^{\mathrm{b}}$, Inon Listyorini \\ ${ }^{a, b, c}$ Universitas Teknologi Yogyakarta, Indonesia \\ septi.diana@uty.ac.id
}

\begin{abstract}
This research aims to test the influence of trust and perceived risk on Actual Online Purchasing (AOP) either directly or through Online Purchase Intention (OPI) as a mediating variable. Purposive Random Sampling used in this research with 100 respondents who have searched product through the E-Commerce website (B2C \& C2C). This research uses Structural Equation Modelling (SEM) model with SmartPLS 3 program. The results of the test showed that Security practice and Privacy Concern have a negative effect on Perceived Risk, which subsequently Perceived Risk has a negative effect on OPI. However, OPI has no significant effect on AOP. Between the two of trust antecedents, the EWOM and Perceived Reputation only Perceived Reputation has a significant influence on the Trust. From the four constructs in this study (AOP, OPI, Trust and Perceived Risk), the Trust Model is the most powerful predictive model compared to other models such as Perceived Risk, OPI, and AOP.
\end{abstract}

Article Info

- Received : October 24, 2019

- Revised : January 9, 2020

- Published : January 18, 2020

- No. Pages : 61-70

- DOI : 10.33019/ijbe.v4i1.248

- JEL : D81, M31

- Keywords : trust, perceived risk, e-wom, perceived reputation, privacy concern

\section{Introduction}

Recently the development of technology is influenced by many things like lifestyle, how to shop and get information, socialize or transact. These change ultimately encourages many companies to change their marketing strategies by using the Internet or digital marketing. Business Model by utilizing the Internet network where the website is used as a medium to conduct business transactions called e-commerce. There are some benefits gained by businessmen by utilizing e-commerce websites; the expansion of marketing or market share without having to open many branches or add many employees, the profit can eventually lower the operational cost, so that companies can sell cheaper and consumers are more interested in purchasing the product. The challenge for companies selling their products through ecommerce is how to make appropriate policies to build customer interest and trust to transact online so that the company can achieve competitive advantage by considering competition in the e-commerce sector is now increasing. IDEA (Indonesian E-Commerce Association) stated that the number of official e-Commerce websites increased from 37 by the end of the year 2017 to 44 in June 2018. Meanwhile APJII, survey stated that there is the number of Internet user increasing sharply from $28.552 \%$ over 20 years (1998-2017), where the most accessible services frequently are chatting services, social media, search engines, see pictures, view 
videos, download videos and images, articles, upload files, email, buy items, register and sell goods. As presented here the activities of selling and buying goods are at the end, It means that Internet utilization for online buying and selling transactions is still relatively low and most users access e-commerce sites only to view or survey prices on the e-commerce website.

Lack of online buying and selling transactions in Indonesia can be caused by several factors that affect online transactions such as risk factors and trusts. Koufaris \& Hampton-sosa (2004) stated that the consumer confidence of e-commerce is one of the key factors for online buying and selling activities. Kim (2008) stated that perceived risk factors and beliefs have a strong influence on the buying interest that leads to purchasing decisions. The belief has a negative impact on the perceived risk in buying online and the belief positively affects the online purchasing intention (Anwar \& Adidarma, 2016). In recent online consumer behavior studies, it was stated that risk and trust are important psychological factors and need to consider for online marketers in establishing its business strategy. Regarding the factors that can increase interest in online purchase, it still needs to study and research more. The results of this research are expected to be utilized for business owners in analyzing the factors affecting the consumer interest in online transactions, as well as additional insight into formulating and implementing business strategies to increase online purchase interest.

\section{Literature Review}

\section{Relationship of Trust and Its Antecedent with Online Purchase Intention}

Trust is one of the elements needed in business transactions, especially in online transactions that are full of uncertainty. E-commerce companies that have a good reputation will usually gain consumer trust. Firmansyah \& Suwarno, (2017) found that perceived reputation positively affects the trust of Internet users in Indonesia to e-commerce systems. In addition, many consumers first check the testimonials of buyers who have shopped on the website, as well as through the media and other online communities to increase the confidence in the transaction. (Tian, Wong, \& Pang, 2018) said that retail online reputation can increase trust that can ultimately increase online purchase interest, but that reputation does not directly influence the purchase interest. Choon \& Corresponding, (2010) stated that trust in online positively affects online purchase intention, concerning Internet coverage, transparency, and accessibility has given new meaning to the WOM concept done conventionally become electronically based, and that is what makes marketers more interested in engaging in E-WOM activities (Kozinets et al., 2010). To exchange product information, customers start using various types of the web such as Customer review sites (testimonials), weblog, social networking sites, online discussion forums, etc. (Lee, Park, \& Han, 2008). Thus, more positive information related to E-Commerce spread over the Internet network can increase the confidence of consumers to buy products through E-Commerce, EWOM positively influences the trust and with the trust can increase the consumers purchase interest through E-Commerce (Puspitasari et al., 2018). Based on the explanation above, the proposed hypothesis is as follows:

H1A: Perceived Reputation has positive effect on Trust

H1B: EWOM has positive effect on Trust

H1C: Trust has a positive effect on OPI (Online Purchase Intention)

\section{Relationship of Perceived Risk and its antecedent with Online Purchase Intention}

McCole, Ramsey, \& Williams, (2010)stated that the risk is related to how a consumer has the confidence to involve technology in the various jobs undertaken by consumers including in terms of finding the required products and purchasing the product. Perceived risk and trust have relationships with each other, where the higher the perceived risk the lower the trust in 
online purchase (D'Alessandro, Girardi, \& Tiangsoongnern, 2012), which can ultimately affect consumer interest (Pappas, 2016). Security practice is an online store's ability to control and maintain the security of consumer transactions (Park \& Kim, 2006). Doolin \& Zealand, (2005) stated that perceived risk is related to security practice and privacy concern, where the higher ability of the company in maintaining the security of the customer's online transactions then the consumer perceived risk will be lower. Security practice and privacy concern applied by the company is crucial considering conducting online transactions will be required to provide personal data and with credit or debit card numbers, so that data security should be well maintained to prevent data or credit card breach. Based on the explanation above, the proposed hypothesis is as follows:

H2A: Security Practice has negative effect on Perceived Risk

H2B: Privacy Concern has negative effect on Perceived Risk

H2C: Perceived Risk has negative effect on the Trust

H2D: Perceived Risk has negative effect on Online Purchase Intention

\section{Relationship between Trust, Perceived Risk, Online Purchase Intention and Actual Online Purchase}

The development of technology-supported with the extended Internet network in Indonesia created a lot of consumers who choose online shopping as one of their shopping media. In which online shopping offers many benefits like they can save their time in choosing products, consumers can compare many variations of goods from different online shop at different prices. The decision of the purchase is an act of selection of various alternatives owned by the consumer, where the decision-making process is initiated from the introduction of problems that are then solved through the purchase of several products (Tjiptono, 2010). While purchase interest is a tendency for respondents to act before purchasing decisions are implemented. Online marketers need to consider that policies promoting trust and reducing risk are important means to increase purchases. In particular, the use of multichannel will reduce the perceived risk. There is an influence between the trust disposition and the risk aversion together against the online purchase intention (Muhibuddin \& Untarini, 2014). The results of the study by (Carlos Roca, Jose Garcia, \& Jose de la Vega, 2009) stated that perceived trust is an important issue in the online trading system when the company enhances the security of online trading systems can increase trust and consequently consumers will tend to use online services. Online purchase intention affects purchasing behavior (Puspitasari et al., 2018). Intentions have been determined as a prominent predictor of actual behavior for online shopping (Lim et al., 2016). Based on the explanation above, the proposed hypothesis is as follows:

H3A: Online Purchase Intention has positive effect on Actual Online Purchase

H3B: Trust affects Actual Online Purchase through Online Purchase Intention as a mediating variable

H3C: Perceived Risk has a negative effect on Actual Online Purchasing through Online Purchase Intention

\section{Research Methods}

This research used quantitative survey method to examine consumer behavior in making online purchasing. Population in this study is the whole E-Commerce user. Sampling is based on purposive random sampling method. The consideration of respondents as a sample is $\mathrm{E}$ Commerce B2C or C2C users and have made transactions in E-Commerce. The number of samples in this study was 100 respondents which mostly are students of the University of Technology Yogyakarta. The data were obtained by using questionnaire. 
Perceived Reputation is a consumer belief that organizations selling goods or services will be honest and caring to consumers. Trust is the willingness of consumers to rely on sellers and to take purchase actions even if the seller can easily harm the consumer. Measurement of Perceived Reputation and Trust refers to the research of McKnight, Choudhury, \& Kacmar (2002). Electronic Word of Mouth is a positive or negative statement made by potential customers, actual customers and former customers about the product or company over the Internet (Hennig-Thurau, T., Gwinner, K.P., Walsh, G., \& Gremler, 2004). The measurement of EWOM refers to an indicator developed by Bambauer-sachse \& Mangold (2011).

Security Practice is a practice in ensuring security as an online store's ability to control and security for data transactions. Privacy concern is a part of data privacy, which involves the right to mandate personal privacy about the storage, provision to third parties, and display information relating to yourself through the Internet. Perceived risk is a way for consumers to perceive possible losses due to online purchase decisions because of the uncertainty of the decision. Online Purchase Intention is a mental activity that precedes it before a decision to buy. Actual Purchase Intention is a concept in purchasing behavior where consumers decide to act/do something and in this case make a purchase electronically. Measurements of Privacy Concern, Perceived Risk and Online Purchase Intention refer to the research by Kim (2008), while Actual Online Purchasing measurement refers to the study by Puspitasari et al. (2018).

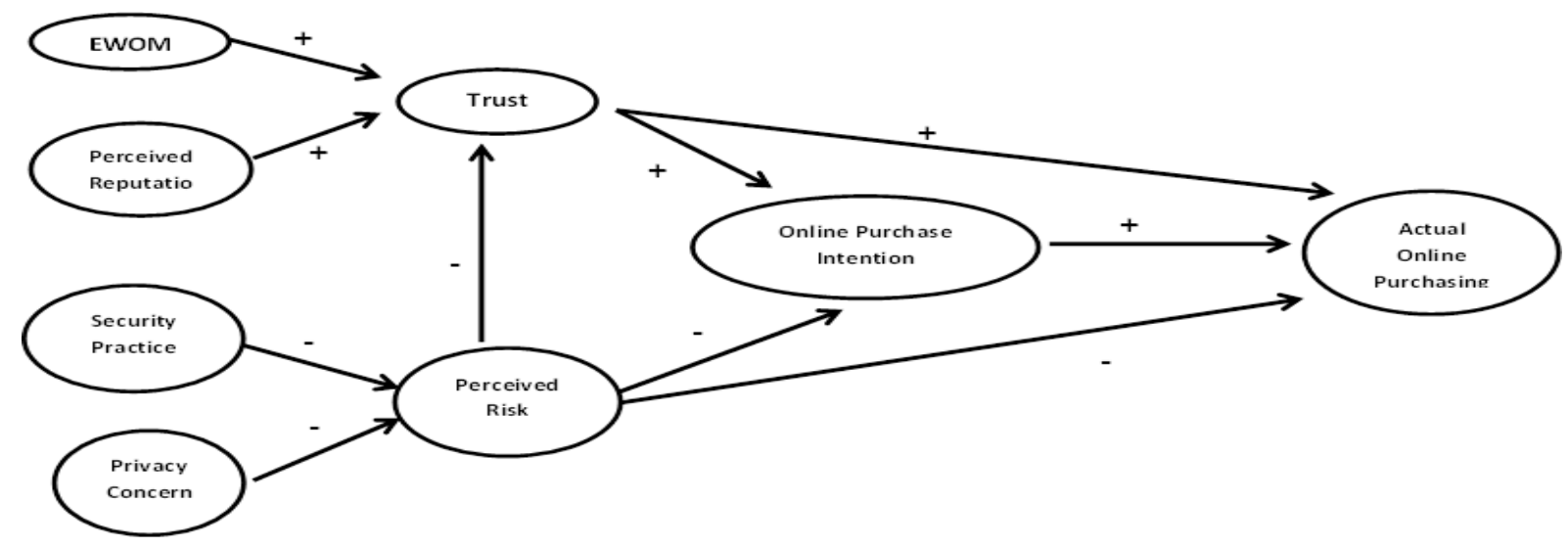

Figure 1. Research Conceptual Framework

Researcher tested the hypotheses using SmartPLS3 program. Outer Model Test (measurement model) was done to specify the relationship between latent / construct variables and indicators. Measurement model to test the validity was done by looking at the AVE value and loading factor values. In confirmatory research, the minimum limit of loading factor that is considered feasible is 0.5 (Ghozali, 2014). Meanwhile, to test reliability by seeing the value of Cronbach's Alpha and Composite Reliability with each value must be above 0.7 (Chin, 1998). Inner Model Test (structural model) conducted to prove the hypothesis. The steps to do the test were looking at R-Square value in endogen construct, which R Square ratings are respectively 0.67 (strong), 0.33 (moderate) and 0.19 (weak) estimate the path coefficients. Path coefficients are scales of the relationship or influence of latent constructs. It was done by Bootstrapping procedure. Hypothesis testing was done by looking at the path coefficient and significance value (level of sig.> 0.5) or by comparing t-table and t-statistic values. If the value of t-statistics > t-table, the hypothesis is supported. T-table value got by using the formula $\mathrm{n}$ (number of samples) - $\mathrm{k}$ (number of variables) - 1 .

\section{Results}




\section{Results of Validity and Reliability Test}

Following table is model measurement result of the validity test using two methods: Outer Loading and AVE value parameters. Reliability test using two methods; Cronbach Alpha and Composite Reliability.

Table 1. Composite Reliability, Cronbach Alpha and AVE

\begin{tabular}{lcccc}
\hline \multicolumn{1}{c}{ Variable } & $\begin{array}{c}\text { Composite } \\
\text { Reliability }\end{array}$ & $\begin{array}{c}\text { Cronbach } \\
\text { Alpha }\end{array}$ & AVE & Note \\
\hline EWOM & 0.911 & 0.881 & 0.632 & Fit \\
\hline Perceived Reputation & 0.917 & 0.864 & 0.786 & Fit \\
\hline Trust & 0.937 & 0.899 & 0.831 & Fit \\
\hline Privacy Concern & 0.917 & 0.878 & 0.734 & Fit \\
\hline Security Practice & 0.907 & 0.866 & 0.667 & Fit \\
\hline Perceived Risk & 0.825 & 0.726 & 0.549 & Fit \\
\hline OPI & 0.920 & 0.896 & 0.658 & Fit \\
\hline
\end{tabular}

Source: Smart PLS output

Validity test result of each variable has an AVE value of $>0.5$ so it is well said that all variables are valid. Meanwhile, reliability test with Composite Reliability and Cronbach Alpha from each variable is above $>0.7$ (Beckett et al., 2017) which indicates that the gauge used in this research is reliable. Convergent validity test, the loading factor value of each question should be greater than 0.5 (Ghozali, 2014). The results of the test in Table 2 indicates that there are no indicators which have loading factor below 0.5 so that it can be inferred that the construct has fulfilled good convergent validity.

\section{Structural Model Test}

This structural model is to evaluate the dependent variable used R-Square values which the higher the value indicates the predictive model used better. Below is the Goodness of Fit test results:

Table 2. Goodness of Fit

\begin{tabular}{ccc}
\hline Variable & R Square & R Square Adjusted \\
\hline AOP & 0.011 & -0.010 \\
\hline OPI & 0.587 & 0.578 \\
\hline Trust & 0.565 & 0.556 \\
\hline Perceived Risk & 0.664 & 0.653 \\
\hline
\end{tabular}

Based on Table 2 above, it shows that the model of online purchase interest in purchasing behavior has a very little $\mathrm{R}$ square value. It shows that purchase interest ability in explaining variations in online purchase behavior is very low (0.011). OPI model shows the Trust and Perceived Risk contributions toward purchase interest by $58.7 \%$, while the antecedent trust influence model has an R-square number of 0.565. Privacy Concern and Security Practice Impact Model of Trust resulted in the greatest value of R Square among other models (0.664), it shows the antecedent model of Trust has the most excellent predictive ability than any other model in this study. The higher value of R-Square indicates that the model is better (Chin, 1998).

To test the hypothesis in the structural model, it can be seen with the line Coefficient values and P-values or T-Statistic of each path. The following is the results of coefficient path test: 


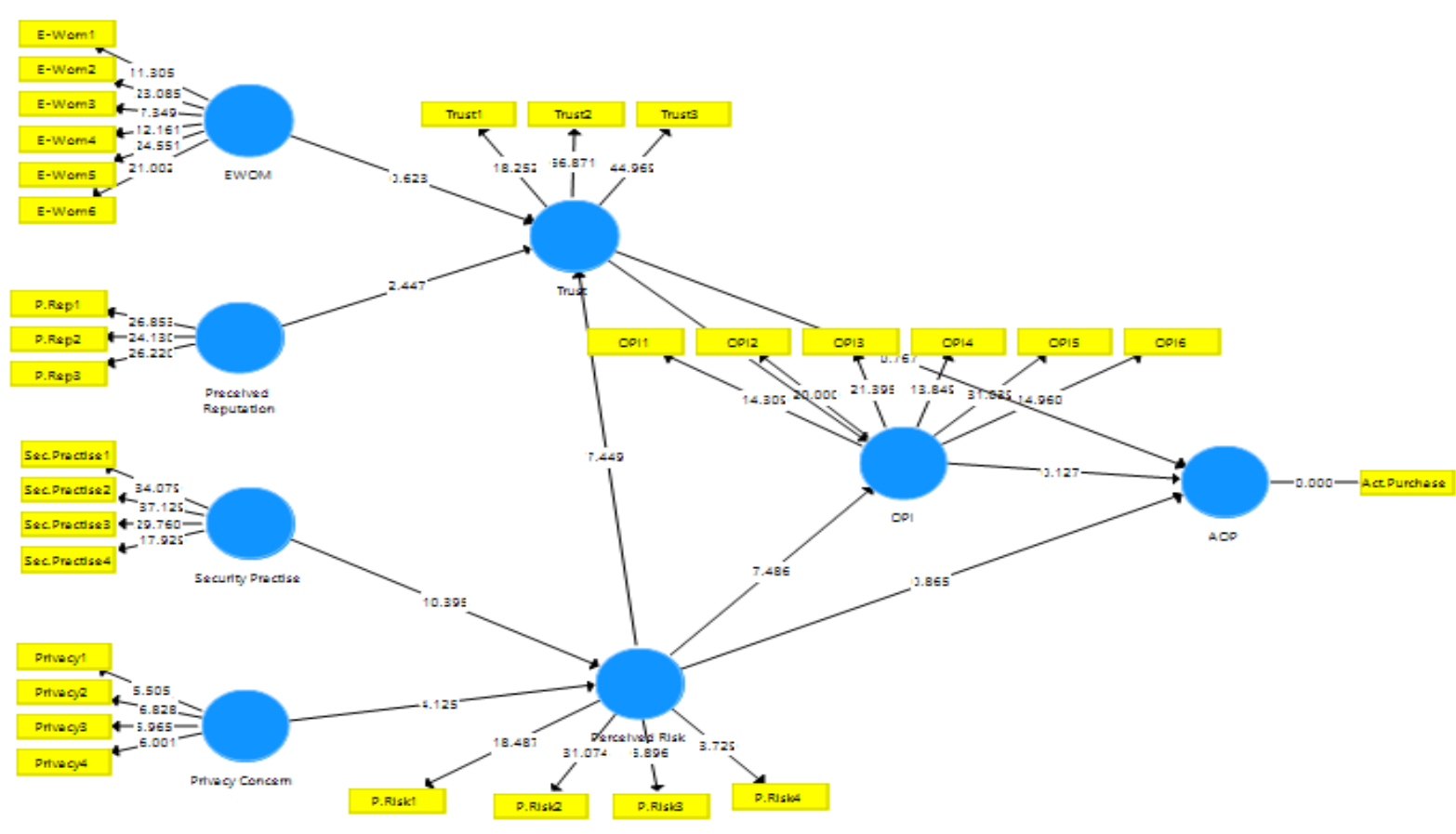

Figure 2. Full SEM Model

Table 3. Structural Model Coefficient Path Testing

\begin{tabular}{|c|c|c|c|c|c|}
\hline Variable & $\begin{array}{l}\text { Original } \\
\text { Sample }\end{array}$ & $\begin{array}{c}\text { Sample } \\
\text { Mean }\end{array}$ & $\begin{array}{c}\text { Standard } \\
\text { Deviation } \\
\end{array}$ & T-Statistic & P-Value \\
\hline \multicolumn{6}{|c|}{ Direct Effect } \\
\hline EWOM*Trust & 0.058 & 0.065 & 0.093 & 0.623 & 0.534 \\
\hline $\begin{array}{l}\text { Perceived } \\
\text { Reputation*Trust }\end{array}$ & 0.256 & 0.248 & 0.105 & 2.447 & $0.015 * *$ \\
\hline Perceived Risk*Trust & -0.577 & 0.583 & 0.007 & 7.449 & $0.000 * *$ \\
\hline Trust*OPI & 0.082 & 0.080 & 0.130 & 0.633 & 0.527 \\
\hline $\begin{array}{l}\text { Security } \\
\text { Practice*Perceived Risk }\end{array}$ & -0.629 & 0.626 & 0.061 & 10.395 & $0.000 * *$ \\
\hline $\begin{array}{l}\text { Privacy } \\
\text { Concern*Perceived Risk }\end{array}$ & -0.324 & 0.320 & 0.079 & 4.125 & $0.000 * *$ \\
\hline Perceived Risk*OPI & -0.747 & 0.750 & 0.055 & 13.496 & $0.000 * *$ \\
\hline OPI*AOP & -0.023 & -0.035 & 0.178 & 0.127 & 0.899 \\
\hline \multicolumn{6}{|c|}{ Total Indirect Effect } \\
\hline EWOM*OPI & 0.005 & 0.007 & 0.016 & 0.301 & 0.764 \\
\hline EWOM*AOP & -0.009 & -0.010 & 0.027 & 0.346 & 0.764 \\
\hline Perceived Reputation*OPI & 0.021 & 0.020 & 0.036 & 0.591 & 0.555 \\
\hline $\begin{array}{l}\text { Perceived } \\
\text { Reputation*AOP }\end{array}$ & -0.001 & -0.000 & 0.004 & 0.158 & 0.875 \\
\hline Privacy Concern*OPI & 0.205 & 0.206 & 0.056 & 3.678 & $0.000 * *$ \\
\hline Privacy Concern*AOP & -0.005 & -0.002 & 0.022 & 0.246 & 0.806 \\
\hline Security Practice*OPI & 0.479 & 0.474 & 0.064 & 7.430 & $0.000 * *$ \\
\hline Security Practice*AOP & -0.013 & -0.0007 & 0.049 & 0.256 & 0.798 \\
\hline Perceived Risk*AOP & -0.02 & -0.018 & 0.077 & 0.254 & 0.800 \\
\hline Trust*AOP & -0.002 & -0.003 & 0.016 & 0.135 & 0.893 \\
\hline
\end{tabular}

Source: Smart PLS output 
The coefficient beta values and the value of T-statistics and significance (P-Value) indicates that the 1A hypothesis stated that Perceived Reputation significantly affects positively on trust is supported $(\beta=0.257$, P-Value $=0.025)$. Unlike the $1 \mathrm{~B}$ hypothesis that EWOM had significant positive effect on Trusts is unsupported $(\beta=0.058, \mathrm{P}-$ Value $=0.553)$. The $1 \mathrm{C}$ hypothesis is unsupported $(\beta=0.083$, P-Value $=0.487)$ indicates that in this case, the Trust on the E-Commerce website does not affect online purchase interest.

Concerning the results of the antecedent of perceived risk test is supported. $2 \mathrm{~A}$ and $2 \mathrm{~B}$ hypothesis indicating that security practice significantly has negative effect on perceived risk $(\beta=-0.641, \mathrm{P}-$ Value $=0.000)$ and privacy concern negatively affects tow ard perceived risk $(\beta$ $=-0.275, \mathrm{P}-$ Value $=0.000)$. The $2 \mathrm{C}$ hypothesis stated that perceived risk negatively affects the trust is also supported $(\beta=-0.576, \mathrm{P}-$ Value $=0.000)$, the $2 \mathrm{D}$ hypothesis is also supported which states that perceived risk negatively affects online purchase interest $(\beta=-0.699$, P-Value $=$ $0.000)$.

The $3 \mathrm{~A}$ hypothesis test shows that OPI had positive effect on the AOP $(\beta=-0.026$, P-Value $=$ 0.801 ). In relation with the role of OPI in the dissemination of the trust (hypothesis $3 \mathrm{~B}$ ) and perceived risk (hypothesis 3C) are not supported as indicated by the Beta and P-value respectively $\beta=-0.002$, $\mathrm{P}-$ Value $=0.893$ for hypothesis $3 \mathrm{~B}$ and $\beta=-0.02, \mathrm{P}-$ Value $=0.800$ for $3 \mathrm{C}$ hypothesis.

\section{Discussion}

\section{Relationship between Trust and its Antecedent with Online Purchase Intention}

Related to trust antecedent; EWOM and reputation perception, it shows that only a reputation perception has positive and significant influence on trust. It means that the E-Commerce website with a good reputation can improve consumer confidence and EWOM has no effect on the trust. The issues related to trust in online purchase behavior are important because in the process of online transactions there is no direct interaction and communication. EWOM in the E-Commerce website in this study is a review (online review) or buyer testimonial related to products sold in the E-Commerce website. Based on the results of the study of the reviews from other consumers, it does not necessarily make consumers or prospective buyers trust. It possibly occurs since there is no social capital bonding among the consumers in e-commerce website since they don't know one another and a belief that the information conveyed by the commentator is honestly given information. In addition, there is usually no detailed identity associated with the review provider so that the credibility can be doubtful. This insignificant outcome with the influence of EWOM on the trust can also be caused by the limitation in this research that does not distinguish E-Commerce model is $\mathrm{B} 2 \mathrm{~B}$ and $\mathrm{C} 2 \mathrm{C}$ (respondents in this research are respondents who have transacted on the $\mathrm{B} 2 \mathrm{~B}$ and $\mathrm{C} 2 \mathrm{C}$ E-Commerce website) in which the E-Commerce model $\mathrm{C} 2 \mathrm{C}$ allows website users to double the role of sellers and buyers that allow the occurrence of cheating in providing information. Dharmaadi \& Supangkat (2014)stated that online review can lead to uncertainty caused by the possibility of manipulation of data from the person giving the review so that there are still a lot of consumers who have not fully trusted E-Commerce website.

Relationship between Perceived Risk and its antecedent with Online Purchase Intention As presented in the structural test model, it shows the online purchase intention influenced by the perception of the risk to the E-commerce website, which the risk perception antecedent is formed by the determination of privacy concern and security practice, each of which has a negative influence and significant to risk perception, but the effect of security practice on perceived risk is greater than privacy concern. Model of perceived risk antecedent shows that 
the E-Commerce Website that considers the security and privacy of consumers can make consumers feel safer or feel a small risk in transaction so that it can eventually increase purchase interest through the E-Commerce website. It can be interpreted that consumers consider risks in building confidence to make online purchases through the E-Commerce website, but in this study having an interest is not enough to explain whether consumers will decide to purchase through the website. This can be explained because it is likely that many consumers use the E-Commerce website only to select and compare products and prices, but they ultimately make purchases on the offline store or COD (Cash on Delivery) system to minimize the risks incurred by consumers.

\section{Relationship between Trust, Perceived Risk, Online Purchase Intention and Actual Online Purchase}

Insignificant results regarding the influence of Online Purchase Intention toward Actual Online Purchase can be caused by limitations in research in which researchers do not distinguish the behavior of purchases on the pure E-Commerce website as in the purchase of digital products or partial E-Commerce websites such as on the purchase of products that usually have a physical form.

\section{Conclusion}

\section{Conclusion}

Based on the results on the previous discussion, it can be concluded that the most powerful predictive model is a model of perceived risk antecedent influence on online purchase interest either directly or through perceived risk. Moreover, the results of hypothesis test between hypotheses 1B, 2A, 2B, 2C and 2D were supported, while the hypotheses of 1C, 1D, 3A, 3B and $3 \mathrm{C}$ were not supported. From these results, it can be stated that marketers in the ECommerce business need to consider and ensure the security of both consumer privacy and the online transaction process. With a sense of security, consumers can reduce the perceived risk of increasing online purchase interest. By reducing consumers ' perceived risks it can also increase trust or consumer confidence in E-Commerce websites. Based on the R-Square value, it can be concluded that the Level of Goodness of Fit from several endogenous variable models which are OPI, Trust and Perceived Risk is categorized as moderate because it has a score between 0.33 - 0.67 While the level of Goodness of fit of the AOP model is considered weak because it is smaller than 0,33 (Chin, 1998).

\section{Suggestion}

About this study results, researcher suggests for the further study to separate purchase behaviors based on online shop type such as online fashion, electronic or general, in which the category of electronic products can be considered to have greater risk compared to fashion products because there is a possibility that electronic products are more risky to suffer damage in the process of goods shipping or goods does not function properly, so it is possible for consumer's online purchase behavior may be different depending on the category of products sold on the website. The results of this research is not able to propose a model that can predict the behavior of online purchases, so that for the further researcher is advised to include other variables of marketing strategies such as sales promotions that can be in the form of discounts, vouchers or other short-term incentive forms, as well as differentiating online purchase behaviors between men and women. Further researchers can distinguish online purchase behavior on pure E-Commerce types with Partial E-Commerce. On the pure E-Commerce products sold are digital products that are only sold through online channels, so consumers who already have the interest to buy may continue the actual purchase process. Unlike Partial ECommerce in which products sold are products that have physical form and consumers have 
an alternative to making purchase transactions both online and offline channels. The further researchers can compare the online purchase behavior through $\mathrm{B} 2 \mathrm{C}$ and $\mathrm{C} 2 \mathrm{C}$ E-Commerce website because the credibility of the two models can differ each other in which the credibility is related to the reputation and the level of consumer confidence in the E-Commerce website.

\section{References}

1) Anwar, R., \& Adidarma, W. (2016). Pengaruh Kepercayaan dan Risiko Pada Minat Beli Belanja Online. Jurnal Manajemen dan Bisnis Sriwijaya, 14(2).

2) Bambauer-sachse, S., \& Mangold, S. (2011). Journal of Retailing and Consumer Services Brand equity dilution through negative online word-of-mouth communication. Journal of Retailing and Consumer Services, 18(1), 38-45. https://doi.org/10.1016/j.jretconser.2010.09.003

3) Beckett, C., Eriksson, L., Johansson, E., \& Wikström, C. (2017). Multivariate Data Analysis (MVDA). In Pharmaceutical Quality by Design: A Practical Approach. https://doi.org/10.1002/9781118895238.ch8

4) Carlos Roca, J., Jose Garcia, J., \& Jose de la Vega, J. (2009). The importance of perceived trust, security and privacy in online trading systems. Information Management \& Computer Security, 17(2), 96-113. Retrieved from https://doi.org/10.1108/09685220910963983

5) Chin, W. W. (1998). The partial least squares approach for structural equation modelling. Modern Methods for Business Research, (January 1998), 295-336.

6) Choon, K., \& Corresponding, L. (2010). The Effects of Shopping Orientations, Online Trust and Prior Online Purchase Experience toward Customers ' Online Purchase Intention. 3(3), 63-76.

7) D'Alessandro, S., Girardi, A., \& Tiangsoongnern, L. (2012). Perceived risk and trust as antecedents of online purchasing behavior in the USA gemstone industry. Asia Pacific Journal of Marketing and Logistics, 24(3), 433-460. https://doi.org/10.1108/13555851211237902

8) Dharmaadi, I. P. A., \& Supangkat, H. (2014). Literature Review: Sistem Reputasi berbasis Feedback Rating pada E-commerce. E-Indonesia Initiatives (EII-Forum).

9) Doolin, B., \& Zealand, N. (2005). Perceived Risk, the Internet Shopping Experience and Online Purchasing Behavior: A New Zealand Perspective. 13(June), 2-5.

10) Firmansyah, D., \& Suwarno, A. E. (2017). Pengaruh Pengalaman, Reputasi, Privasi, Dan Keamanan Terhadap Kepercayaan (Trust) Pengguna Internet Dalam Melakukan Transaksi Jual Beli Online (studi empiris pada masyarakat di Surakarta) (Universitas Muhammadiyah Surakarta). https://doi.org/10.1002/ejsp.2570

11) Ghozali, I. (2014). Structural Equation Modeling: Metode Alternatif Dengan Partial Least Squares $(P L S)$ (4th ed.). Semarang: Universitas Diponegoro Semarang.

12) Hennig-Thurau, T., Gwinner, K.P., Walsh, G., \& Gremler, D. D. (2004). Electronic Word-OfMouth Via Consumer-Opinion Platforms: What Motivates Consumers To Articulate Themselves On The Internet? https://doi.org/10.1002/dir.10073

13) Kim, D. J. (2008). A trust-based consumer decision-making model in electronic commerce: The role of trust, perceived risk, and their antecedents. Decision Support Systems, 44(2), 544-564. https://doi.org/10.1016/j.dss.2007.07.001

14) Koufaris, M., \& Hampton-sosa, W. (2004). The development of initial trust in an online company by new customers. 41, 377-397. https://doi.org/10.1016/j.im.2003.08.004

15) Kozinets, R. V, Valck, K. De, Wojnicki, A. C., \& Wilner, S. J. S. (2010). Networked Narratives : Understanding Word-of-Mouth. Journal of Marketing, 74(March), 71-89.

16) Lee, J., Park, D.-H., \& Han, I. (2008). The effect of negative online consumer reviews on product attitude: An information processing view. Electronic Commerce Research and Applications, 7(3), 
341-352. Retrieved from https://doi.org/10.1016/j.elerap.2007.05.004

17) Lim, Y. J., Osman, A., Salahuddin, S. N., Romle, A. R., \& Abdullah, S. (2016). Factors Influencing Online Shopping Behavior: The Mediating Role of Purchase Intention. Procedia Economics and Finance, 35(October 2015), 401-410. https://doi.org/10.1016/s2212-5671(16)00050-2

18) McCole, P., Ramsey, E., \& Williams, J. (2010). Trust considerations on attitudes towards online purchasing: The moderating effect of privacy and security concerns. Journal of Business Research, 63(9-10), 1018-1024. https://doi.org/10.1016/j.jbusres.2009.02.025

19) McKnight, H., Choudhury, V., \& Kacmar, C. (2002). Developing and Validating Trust Measures for e-Commerce: An Integrative Typology. Information System Research, 13(3), 334-359.

20) Muhibuddin, ali S., \& Untarini, N. (2014). Pengaruh Trust Disposition dan Risk Aversion Terhadap Niat Beli Online Pada Fjb Kaskus Di Wilayah Surabaya. Jurnal Ilmu Manajemen, 2(4).

21) Pappas, N. (2016). Marketing strategies, perceived risks, and consumer trust in online buying behaviour. Journal of Retailing and Consumer Services, (29), 92-103.

22) Park, C.-H., \& Kim, Y.-G. (2006). The Effect of Information Satisfaction and Relational Benefit on Consumers' Online Shopping Site Commitments. Journal of Electronic Commerce in Organizations (JECO), 4(1), 21. https://doi.org/10.4018/jeco.2006010105

23) Puspitasari, N. B., Nugroho Susatyo, W. P., Amyhorsea, D. N., \& Susanty, A. (2018). Consumer's Buying Decision-Making Process in E-Commerce. E3S Web of Conferences, 31(September 2016), 1-6. https://doi.org/10.1051/e3sconf/20183111003

24) Tian, V.-I., Wong, Y.-S. E., \& Pang, W. (2018). Creating Trust and Reducing Consumers' Risk Perception in Internet Shopping. Journal of Marketing Development and Competitiveness, 12(1). https://doi.org/https://doi.org/10.33423/jmdc.v12i1.1415

25) Tjiptono, F. (2010). Strategi Pemasaran (3rd ed.). Yogyakarta: Andi. 